\title{
Decreased Hypothalamic Growth Hormone-releasing Hormone Content and Pituitary Responsiveness in Hypothyroidism
}

Hideki Katakami, Thomas R. Downs, and Lawrence A. Frohman

Division of Endocrinology and Metabolism, Department of Internal Medicine, University of Cincinnati

College of Medicine, Cincinnati, Ohio 45267

\section{Abstract}

The effects of thyroidectomy (Tx) and thyroxine replacement $\left(T_{4} R x\right)$ on pituitary growth hormone (GH) secretion and hypothalamic GH-releasing hormone (GRH) concentration were compared to define the mechanism of hypothyroid-associated GH deficiency.

Thyroidectomized rats exhibited a complete loss of pulsatile GH secretion with extensive reduction in GRH responsiveness and pituitary GH content. Cultured pituitary cells from Tx rats exhibited reduced GRH sensitivity, maximal GH responsiveness, and intracellular cyclic AMP accumulation to GRH, while somatostatin (SRIF) suppressive effects on GH secretion were increased. Hypothalamic GRH content was also markedly reduced. $T_{\mathbf{4}} R x$ completely restored hypothalamic GRH content and spontaneous GH secretion despite only partial recovery of pituitary GH content, GRH and SRIF sensitivity, and intracellular cyclic AMP response to GRH.

The results indicate multiple effects of hypothyroidism on GH secretion and suggest that a critical role of $T_{4}$ in maintaining normal GH secretion, in addition to restoring GH synthesis, is related to its effect on hypothalamic GRH.

\section{Introduction}

Growth hormone $(\mathrm{GH})^{1}$ secretion requires the presence of thyroid hormones, which have been shown to exert important effects on GH messenger RNA (mRNA) transcription and hormone biosynthesis (1). Consequently, in both man and experimental animals, thyroid hormone deficiency is associated with an impairment in $\mathrm{GH}$ secretion that has been attributed to decreased somatotroph GH content (2-7). Thyroxine or triiodothyronine treatment of hypothyroid animals restores both $\mathrm{GH}$ secretion and pituitary GH content to normal $(8,9)$.

Attention has recently been given to a possibly broader role of thyroid hormones in the regulation of $\mathrm{GH}$ secretion as further knowledge of the central nervous system (CNS) control of GH

Address correspondence to Dr. Frohman, Division of Endocrinology and Metabolism, ML 547, University of Cincinnati College of Medicine, 231 Bethesda Avenue, Cincinnati, OH 45267.

Received for publication 16 September 1985 and in revised form 14 January 1986.

1. Abbreviations used in this paper: $\mathrm{ACN}$, acetonitrile; $\mathrm{GH}$, growth hormone; GRH, growth-releasing hormone; hGRH, human GRH; rGRH, rat GRH; SRIF, somatostatin; $T_{\mathbf{4}} R x$, thyroxine replacement; TSH, thyrotropin; Tx, thyroidectomized.

J. Clin. Invest.

(c) The American Society for Clinical Investigation, Inc.

0021-9738/86/05/1704/08 $\$ 1.00$

Volume 77, May 1986, 1704-1711 has accumulated. It is now recognized that GH secretion is modulated by stimulatory and inhibitory hypothalamic peptides: GH-releasing hormone (GRH) and somatostatin (SRIF), respectively. Previous studies from this laboratory have demonstrated significant decreases in both the hypothalamic content and release of SRIF in hypothyroid rats (10). These changes, which would not contribute to a decrease in GH secretion, are the results of either a primary consequence of thyroid hormone deficiency on somatostatinergic neurons or are secondary to the reduced secretion of GH (11).

The isolation and characterization of $\operatorname{GRH}(12,13)$ has made possible the study of additional potential sites of thyroid hormone action. Thyroid hormone deficiency has been reported to impair the GH secretory responses to GRH in rat pituitary monolayer cultures (14) and in vivo in the rat (15) and man (16). None of these reports addressed the mechanism of this effect, however, and in all diminished pituitary GH stores could explain the results.

The present study was designed to further assess the effect of thyroid hormone deficiency and replacement on GH secretion and to study the underlying mechanisms using both in vivo and in vitro techniques. For this purpose we evaluated spontaneous and GRH-stimulated GH secretion in conscious rats and the effects of GRH and SRIF on GH release and cAMP accumulation in vitro. In addition, the effect of thyroid hormone deficiency on hypothalamic GRH content was examined by a specific radioimmunoassay.

\section{Methods}

Animals. Adult male Sprague-Dawley rats that had undergone either surgical thyroidectomy or sham operation at the age of $8 \mathrm{wk}$, were purchased from Harlan Industries Inc. (Indianapolis, IN). The animals were housed for at least $4 \mathrm{wk}$ after arrival in an environmentally controlled room (lights on: $0600-1800 \mathrm{~h}$, temperature: $23 \pm 1^{\circ} \mathrm{C}$ ), with water and food provided ad libitum. Intravenous cannulae were then implanted into the right atrium as previously described (17). After cannulation, animals were caged individually, handled and weighed daily by the same investigator, and adapted to specific blood sampling procedures (18). The animals were divided into three groups 2 wk after cannulation, when body weight and behavior had returned to preoperative levels. The two groups of thyroidectomized animals were injected daily at $1700 \mathrm{~h}$ with saline, $0.1 \mathrm{ml} / 100 \mathrm{~g}$, (Tx) or L-thyroxine, $2 \mu \mathrm{g} / 100 \mathrm{~g}$, $\left(\mathrm{T}_{4} \mathrm{Rx}\right)$ through the indwelling cannula for a period of $7 \mathrm{~d}$. The sham-operated controls of the third group were injected with saline in a similar manner. Three separate experiments were performed at $1-w k$ intervals using the identical protocol. The results of each experiment were similar and have therefore been combined. A total of 30 animals, 10 in each of the three groups, was studied.

Evaluation of spontaneous $G H$ secretion and $G R H$ responsiveness in vivo. On the fifth day, blood samples $(0.2 \mathrm{ml})$ were withdrawn from the intraatrial cannula at 10-20-min intervals from 1000 to $1400 \mathrm{~h}$ to assess the pattern of spontaneous GH secretion. All blood samples were immediately centrifuged and the plasma was separated and stored at $-20^{\circ} \mathrm{C}$ 
for subsequent GH and thyrotropin (TSH) radioimmunoassay (RIA). After blood sampling, erythrocytes were resuspended in saline and returned to the same animal after collecting the subsequent blood sample. On the seventh day, the animals were injected with human GRH-(140)-OH (hGRH), $1 \mu \mathrm{g} / 100 \mathrm{~g}$, (kindly provided by Dr. J. Rivier, Salk Institute, San Diego, CA) at $1100 \mathrm{~h}$ when plasma $\mathrm{GH}$ concentrations were expected to be at trough levels (17-19) and the blood sampling procedure was repeated. hGRH was dissolved in acidified saline $(\mathrm{pH}$ 4.0) containing $1 \%$ albumin at a concentration of $10 \mu \mathrm{g} / \mathrm{ml}$ just prior to injection through the indwelling cannula.

Cell dissociation and in vitro incubation protocol. On the eighth day, the animals were killed by decapitation and hypothalami, anterior pituitary glands, and trunk blood were collected. The anterior pituitaries from each group of animals were enzymatically dissociated according to previously described methods (20). The resultant cell suspension from each of the three groups of animals was counted, individually adjusted to $10^{7}$ cells $/ \mathrm{ml}$ and $25-\mu \mathrm{l}$ aliquots $\left(2.5 \times 10^{5}\right.$ cells $)$ were plated onto the surface of 24-well culture plates (Costar, Data Packaging, Cambridge, MA). After a 1-h cell attachment period, the cells were flooded with 1.0 $\mathrm{ml}$ of culture medium. Pituitary cells prepared from hypothyroid animals were cultured for $3 \mathrm{~d}$ in bicarbonate-buffered Alpha-modified Eagle's medium (AMEM, Gibco, Grand Island, NY) containing gentamicin sulfate, $25 \mu \mathrm{g} / \mathrm{ml}$, (Gibco) and supplemented with $10 \%$ fresh rat serum, which was obtained from the same $T x$ animals at decapitation. Cells from control and $T_{4} R x$ rats were cultured in AMEM supplemented with the corresponding fresh autologous serum (10\%). Three adenohypophyses from each group of animals yielded a sufficient number of cells for 1518 groups of quadruplicate incubation wells. Aliquots of the freshly dispersed pituitary cells $(25 \mu \mathrm{l})$ were also extracted in $1.0 \mathrm{ml} 0.01 \mathrm{M} \mathrm{NaOH}$ for $30 \mathrm{~min}$ at $4^{\circ} \mathrm{C}$ and centrifuged for $30 \mathrm{~min}$ at $2,500 \mathrm{~g}$. A $0.5-\mathrm{ml}$ aliquot of the supernatant was neutralized with $0.5 \mathrm{ml} 0.01 \mathrm{M} \mathrm{HCl}$, buffered with $1.0 \mathrm{ml}$ of $0.05 \mathrm{M}$ phosphate-buffered saline (PBS), $\mathrm{pH} 7.5$, containing $1 \%$ bovine serum albumin (BSA), and stored at $-20^{\circ} \mathrm{C}$ for determination of intracellular $\mathrm{GH}$ content.

After $3 \mathrm{~d}$ of culture, the medium was removed and replaced with $1.0 \mathrm{ml}$ AMEM containing $0.1 \%$ BSA. After a $30-60$-min preincubation period, the wash medium was replaced with fresh medium to a final volume of $1.0 \mathrm{ml}$. Synthetic hGRH or SRIF (Sigma Chemical Co., St. Louis, MO) was dissolved in PBS containing $1 \%$ BSA, added to quadruplicate wells in 50- $\mu$ l aliquots and the cells were incubated for $4 \mathrm{~h}$ at $37^{\circ} \mathrm{C}$. The medium was removed and stored at $-20^{\circ} \mathrm{C}$ for subsequent GH RIA. Cells were extracted for intracellular GH content in $0.01 \mathrm{M}$ $\mathrm{NaOH}$ as described or with $0.1 \mathrm{M} \mathrm{HCl}$ in $95 \%$ ethanol for intracellular cAMP determination (21). The data presented represent the pooled results of three separate pituitary cell dispersions, each consisting of three or four animals from each of the experimental groups.

Hypothalamic tissue collection and extraction. Individual rat hypothalami from each animal were collected at the time of decapitation according to the following landmarks: anterior, posterior, and lateral borders, and depth of dissection were at the optic chiasm, anterior border of the mammillary body, hypothalamic sulci, and $1.5 \mathrm{~mm}$ from the pituitary stalk, respectively. The hypothalamic fragments were rapidly dissected, frozen on dry ice, and stored at $-80^{\circ} \mathrm{C}$ until subsequent extraction.

Individual frozen hypothalami were weighed and immediately added to test tubes containing $0.5 \mathrm{ml}$ of $2 \mathrm{M}$ acetic acid, and the tubes were boiled for $5 \mathrm{~min}$. The tissues were individually homogenized with a glass-teflon homogenizer. The homogenates were centrifuged at 10,000 $g$ for $10 \mathrm{~min}$ at $4^{\circ} \mathrm{C}$ and the supernatants were lyophilized and stored at $-20^{\circ} \mathrm{C}$ for subsequent rat GRH (rGRH) measurement. Recovery of rGRH added prior to extraction was $75 \%$.

Rat GH, TSH, cAMP, and thyroxine RIA. Rat GH and TSH were measured by specific RIAs, as previously described $(22,23)$ and the results were expressed in terms of NIADDK rGH and rTSH RP-1 reference standards. The intra- and interassay coefficients of variation were 4.5 and $10.8 \%$, respectively, for the $\mathrm{rGH}$ assay. The minimum detectable plasma GH level was $4.0 \mathrm{ng} / \mathrm{ml}$. Plasma levels below this value were treated as $4.0 \mathrm{ng} / \mathrm{ml}$ for statistical analysis. All rTSH measurements were performed in a single assay that exhibited a $6.9 \%$ coefficient of variation. The minimum detectable plasma TSH level was $40 \mathrm{ng} / \mathrm{ml}$. cAMP was measured with a kit purchased from New England Nuclear, Boston, MA. Plasma thyroxine was measured on a Becton-Dickinson Immunodiagnostics (Oxnard, CA) ARIA-HT system.

RIA for rat GRH. Synthetic rat GRH (Peninsula Laboratories, Belmont, CA) was dissolved in $0.05 \mathrm{M}$ acetic acid at a concentration of 200 $\mu \mathrm{g} / \mathrm{ml}$, and 5- $\mu \mathrm{l}$ aliquots were lyophilized in $400-\mu \mathrm{l}$ polypropylene tubes. Prior to iodination an aliquot was resuspended in $10 \mu \mathrm{l}$ of $0.05 \mathrm{M}$ acetic acid, followed by the addition of $20 \mu \mathrm{l} 0.5 \mathrm{M}$ sodium phosphate buffer, pH 7.5, $200 \mu \mathrm{Ci}(2 \mu \mathrm{l}){ }^{125} \mathrm{I}-\mathrm{Na}$ (Amersham Corp., Arlington Heights, IL), and $5 \mu$ l chloramine $\mathrm{T}$ solution $(0.5 \mathrm{mg} / \mathrm{ml}$ in PBS). The solution was mixed briefly and allowed to react for $30 \mathrm{~s}$ before the reaction was terminated by the addition of $5 \mu \mathrm{l}$ sodium metabisulfite solution (3.0 $\mathrm{mg} / \mathrm{ml}$ in PBS) and $10 \mu \mathrm{l}$ of PBS containing $1 \%$ BSA.

Iodinated rGRH was purified by high performance liquid chromatography using a $250 \times 4.6 \mathrm{~mm}$ Vydac $201 \mathrm{TP}$ reverse-phase $\left(C_{18}\right)$ column (The Separations Group, Vydac, Hesperia, CA) containing $5 \mu \mathrm{M}$ sorbant that was previously equilibrated to $30 \%$ acetonitrile (ACN)/70\% $0.01 \mathrm{M}$ trifluoracetic acid (TFA). The iodination mixture was injected onto the column and eluted with a 30-36\% ACN/TFA gradient over a 6-min period, followed by a $36-40 \%$ ACN/TFA gradient over the next 16 min. A flow rate of $1.0 \mathrm{ml} / \mathrm{min}$ was used and $1-\mathrm{min}$ fractions were collected for the duration of the elution. Free ${ }^{125} \mathrm{I}-\mathrm{Na}$ eluted in the void volume and ${ }^{125}$ I-rGRH eluted in two peaks between 37 and $39 \%$ ACN. These fractions were dried under nitrogen at room temperature and reconstituted in $0.5 \mathrm{ml}$ of $0.2 \mathrm{M}$ acetic acid containing $0.5 \% \mathrm{BSA}, 0.2 \% \beta$-mercaptoethanol and $0.01 \%$ Triton X-100, and stored at $4{ }^{\circ} \mathrm{C}$. ${ }^{125} \mathrm{I}-\mathrm{rGRH}$ prepared and stored in this manner was stable for RIA use for 4-6 wk. Typically, the best specific binding activity was found in the fractions that eluted just prior to and including the peak fraction of the first ${ }^{125} \mathrm{I}$ rGRH peak.

Synthetic rGRH $(400 \mu \mathrm{g})$ was conjugated to $12 \mathrm{mg}$ of keyhole limpet hemocyanin (Calbiochem-Behring Corp., Div. of American Hoechst Corp., La Jolla, CA) in $800 \mu$ l distilled water by mixing the solution for $3 \mathrm{~h}$ at room temperature in the presence of $0.22 \%$ carbodiimide $(900 \mu \mathrm{l}$ final volume). The mixture was dialyzed against distilled water for $24 \mathrm{~h}$ at $4^{\circ} \mathrm{C}$.

Female New Zealand albino rabbits $(2.5-3.0 \mathrm{~kg})$ were injected subcutaneously at multiple sites with $1.0 \mathrm{ml}$ of an equal mixture (vol/vol) of rGRH conjugate and Freund's complete adjuvant with an initial immunizing dose of $100 \mu \mathrm{g} \mathrm{rGRH}$. The animals received booster injections of $50 \mu \mathrm{g}$ rGRH in Freund's incomplete adjuvant at monthly intervals. Antibodies were detected in all rabbits within 8 wk after the initial immunization and maximal titers were achieved by $5 \mathrm{mo}$.

The rGRH antiserum (No. 442) used in the present study at a final dilution of 1:17,500 exhibited no significant cross-reactivity $\left(<10^{-4} \mathrm{M}\right)$ with rat corticotropin-releasing factor, peptide histidyl isoleucine, vasoactive intestinal polypeptide, glucagon, secretin, gonadotropin releasing hormone, thyrotropin-releasing hormone, gastric inhibitory polypeptide, gastrin releasing peptide, cholecystokinin-8, neurotensin, substance $P$, somatostatin 28 , SRIF, angiotensin I, and rat GH, TSH, or prolactin. The cross-reactivity of the antiserum with several synthetic fragments of human GRH (hGRH-1-20-NH $\mathrm{NH}_{2}$ and hGH-1-32- $\mathrm{NH}_{2}$ ) was also negligible $\left(<10^{-4} \mathrm{M}\right)$; however, the anti-rat GRH serum did crossreact with hGRH-1-40-OH and hGRH-1-44-NH $\mathrm{NH}_{2}$ at $\sim 0.005 \%$.

rGRH standards were dissolved in $0.2 \mathrm{M}$ acetic acid containing $0.5 \%$ crystalline BSA at a concentration of $1.0 \mu \mathrm{g} / \mathrm{ml}$. Aliquots of $0.1 \mathrm{ml}(100$ ng) were pipetted into $12 \times 75-\mathrm{mm}$ polypropylene tubes, lyophilized, and stored at $-70^{\circ} \mathrm{C}$. A fresh aliquot was diluted to the appropriate working concentrations $(0.1-10 \mathrm{ng} / \mathrm{ml})$ with assay buffer, comprised of PBS containing $0.5 \%$ BSA, $0.01 \%$ Triton X-100, and $0.1 \%$ alkaline-treated casein (24), pH 7.5, for each assay.

For the rGRH assay, $0.1 \mathrm{ml}$ of standard or sample and $0.1 \mathrm{ml}$ of anti-rGRH serum (in assay buffer containing $1 \%$ normal rabbit serum) were added to $10 \times 75-\mathrm{mm}$ flint glass test tubes on ice and diluted to $0.45 \mathrm{ml}$ final volume with assay buffer. After a 16-18-h incubation at $4^{\circ} \mathrm{C}, \sim 5,000 \mathrm{cpm}{ }^{125} \mathrm{I}$-rGRH tracer was added in $50 \mu \mathrm{l}$ assay buffer. 
After a further 48 -h incubation at $4^{\circ} \mathrm{C}, 0.1 \mathrm{ml}$ goat anti-rabbit gamma globulin was added and the tubes incubated at $4^{\circ} \mathrm{C}$ for an additional 18-24 h. Antigen-antibody complexes were precipitated by centrifugation at $1,500 \mathrm{~g}$ for $20 \mathrm{~min}$ at $4^{\circ} \mathrm{C}$ and the supernatants were aspirated. The pellets were washed with $0.3 \mathrm{ml}$ PBS containing $0.2 \%$ BSA and the tubes recentrifuged. The precipitates were counted and the data analyzed by a weighted log-logit method. The intra- and interassay coefficients of variation, as determined by a pool of rat hypothalamic extract, were 7.8 and $10.0 \%$, respectively, at a level of $100 \mathrm{pg} /$ tube rGRH. The dilution curve of rat hypothalamic extract was parallel to that of the synthetic rGRH standard. The sensitivity of the rGRH assay was between 5 and $8 \mathrm{pg} /$ tube, with half-maximal displacement of $\sim 125 \mathrm{pg} /$ tube.

Statistical analysis. The integrated spontaneous GH secretion was determined by measuring the area subscribed by the plasma $\mathrm{GH}$ values during the specified time interval. The significance of differences between groups was determined by a single factor analysis of variance with Duncan's new multiple range test and by a two-factor analysis of variance using a repeated measures design (SAS, SAS Institute, Cary, NC) as performed on a Digital VAX-750 computer. Analysis of the in vitro dose response curves (origin, slope, $\mathrm{ED}_{50}$, and maximal response) to GRH was performed using the ALLFIT program (25) that provides a least squares fit to a four parameter logistic function. A $P$ value of $<0.05$ was considered statistically significant. The results of the inhibitory responses to SRIF did not fulfill the criteria for such an analysis and were therefore compared by covariance analysis (26).

\section{Results}

Effect of thyroidectomy on spontaneous GH secretion. Thyroidectomized rats exhibited impaired weight gain as compared with controls ( $68 \pm 5$ vs. $155 \pm 5 \mathrm{~g}$ ) during the $37-\mathrm{d}$ period of observation and plasma TSH levels were also markedly elevated $(12,444 \pm 757$ vs. $579 \pm 101 \mathrm{ng} / \mathrm{ml}, P<0.001)$. Plasma TSH levels in thyroxine- replaced $\left(T_{4} R x\right)$ rats were markedly reduced $(2,200 \pm 631 \mathrm{ng} / \mathrm{ml})$ but still elevated as compared with controls $(P<0.01)$. During treatment $T_{4} R x$ animals demonstrated significant weight gain $(9.7 \pm 1.6 \mathrm{~g})$ as compared with TX rats $(0.03 \pm 1.4 \mathrm{~g}, P<0.01)$ but only half as much as controls $(17.5 \pm 2.0 \mathrm{~g}, P<0.01)$. Plasma $T_{4}$ levels in control, $T x$, and $T_{4} R x$ rats were $1.24 \pm 0.09$, undetectable, and $2.42 \pm 0.33 \mathrm{ng} / \mathrm{dl}$, respectively.

GH secretion in control animals was pulsatile, with spontaneous GH secretory bursts occurring between 1120 and 1300 $h$ in individual animals (Fig. 1). In contrast, Tx animals showed a virtually complete loss of spontaneous $\mathrm{GH}$ secretion. Integrated GH secretion during the 4-h period was decreased by $91 \%$ from that in control rats $(P<0.001)$ (Table I). Treatment of Tx animals with $\mathrm{T}_{4}$ for $4 \mathrm{~d}$ resulted in a return of spontaneous $\mathrm{GH}$ secretion with an integrated $\mathrm{GH}$ secretion statistically indistinguishable $(93 \%)$ from that of controls.

Effect of thyroidectomy on the in vivo GH secretory response to $G R H$. Intravenous injection of hGRH $(1 \mu \mathrm{g} / 100 \mathrm{~g})$ into control rats at $1100 \mathrm{~h}$ led to a rapid increase in plasma $\mathrm{GH}$ levels followed by an equally rapid decline (Fig. 2). The expected spontaneous GH secretion was either delayed or did not occur during the experimental period. Tx rats exhibited a $98 \%$ reduction $(P$ $<0.001$ ) in the peak secretory response and a $95 \%$ reduction in the integrated response to hGRH (Table I). $T_{4}$ treatment of Tx animals for $6 \mathrm{~d}$ partially restored the peak and integrated plasma GH responses to hGRH to 37 and 50\%, respectively, of controls $(P<0.001$ vs. both $\mathrm{Tx}$ and control).

Effect of thyroidectomy on pituitary $\mathrm{GH}$ content and basal $G H$ release in vitro. Pituitary GH content, as measured in dispersed pituitary cells at the time of plating, was reduced in $\mathrm{Tx}$ cells to $<1 \%$ of that in control cells $(124 \pm 8$ vs. $34,446 \pm 1,115$

\section{CONTROL}

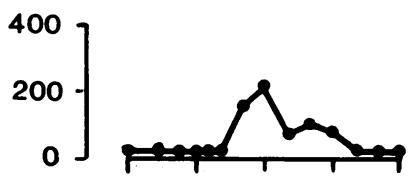

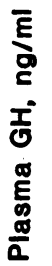
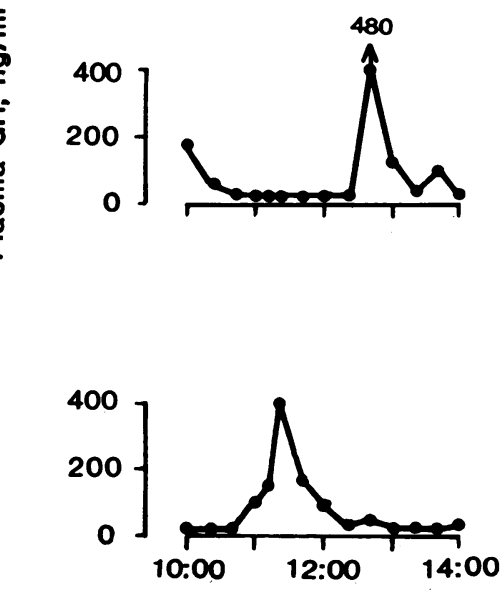

HYPOTHYROID

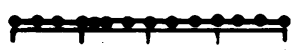

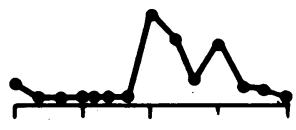

\section{HYPOTHYROID + T4}
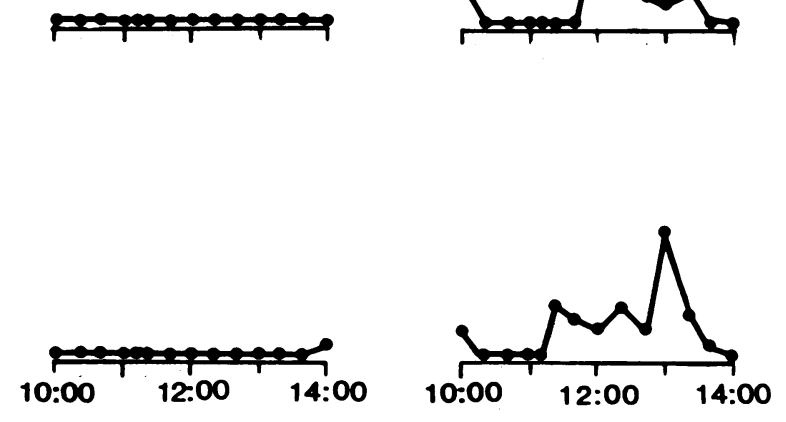

Time of Day
Figure 1. Spontaneous GH secretory profiles obtained from three individual control, thyroidectomized, and thyroidectomized - thyroxine treated animals. Blood samples were collected every 10 $20 \mathrm{~min}$ from 1000 to $1400 \mathrm{~h}$. 
Table I. Effect of Thyroidectomy on Spontaneous and GRHstimulated GH Secretion

\begin{tabular}{|c|c|c|c|}
\hline & & $\begin{array}{l}\text { Integrated GH } \\
\text { secretion }\end{array}$ & $\begin{array}{l}\text { Repeated measures } \\
\text { multivariate analysis } \\
\text { (effect of treatment) }\end{array}$ \\
\hline & $n$ & $n g \times m l^{-1} \times \min$ & \\
\hline $\begin{array}{l}\text { Spontaneous } \\
\text { secretion }\end{array}$ & & $(1000-1400 \mathrm{~h})$ & \\
\hline Control & 10 & $34,745 \pm 5,325^{*}$ & \\
\hline Hypothyroid & 10 & $3,169 \pm 567 \ddagger$ & $\begin{array}{c}P<0.001 \text { vs. } \\
\text { control }\end{array}$ \\
\hline $\begin{array}{l}\text { Hypothyroid } \\
\quad+T_{4}\end{array}$ & 9 & $32,142 \pm 2,958$ & $\begin{array}{r}P<0.001 \text { vs. } \\
\text { hypothyroid }\end{array}$ \\
\hline $\begin{array}{l}\text { GRH-stimulated } \\
\text { secretion }\end{array}$ & & $(1100-1200 h)^{\prime \prime}$ & \\
\hline Control & 9 & $28,307 \pm 2,435$ & \\
\hline Hypothyroid & 10 & $1,385 \pm 230 \ddagger$ & $\begin{array}{c}P<0.001 \text { vs. } \\
\text { control }\end{array}$ \\
\hline $\begin{array}{l}\text { Hypothyroid } \\
\quad+T_{4}\end{array}$ & 10 & $14,279 \pm 1,976 \S$ & $\begin{array}{c}P<0.001 \text { vs. } \\
\text { control } \\
P<0.001 \text { vs. } \\
\text { hypothyroid }\end{array}$ \\
\hline
\end{tabular}

* Mean \pm SE.

$\ddagger P<0.001$ vs. both control and hypothyroid $+\mathrm{T}_{4}$ (single factor analysis of variance).

$\S P<0.001$ vs. control (single factor analysis of variance).

${ }^{"}$ Animals were injected with hGRH $(1 \mu \mathrm{g} / 100 \mathrm{~g}$, i.v. $)$ at $1100 \mathrm{~h}$.

$\mathrm{ng} / 2.5 \times 10^{5}$ cells, $\left.n=12, P<0.001\right)$. Cells from $\mathrm{T}_{4} \mathrm{Rx}$ animals contained $37 \%$ as much $\mathrm{GH}\left(12,773 \pm 1,204 \mathrm{ng} / 2.5 \times 10^{5}\right.$ cells, $P<0.001)$ as did control cells. However, after $3 \mathrm{~d}$ in culture, basal GH release during the 4-h incubation period reflected cell content ( $4 \mathrm{~h}$ medium $\mathrm{GH}$ plus intracellular $\mathrm{GH}$ remaining at end of $4 \mathrm{~h}$ incubation), resulting in almost identical $\mathrm{GH}$ release rates, when calculated as a percentage of total cell content (Fig. 3).

To normalize for the large differences in intracellular $\mathrm{GH}$ content among the three groups, all GH responses to GRH were expressed as a percentage of intracellular $\mathrm{GH}$ content. However, analysis of the results using the absolute levels of medium $\mathrm{GH}$ or the percentage of GRH-stimulated increase above basal GH release also resulted in group differences that were similar in all respects.

Effect of thyroidectomy on pituitary $G H$ responses to $G R H$. Exposure of control cells to hGRH at concentrations from 0.01 $\mathrm{nM}$ to $13 \mathrm{nM}$ resulted in a maximal 5.5-fold increase in $\mathrm{GH}$ release with a calculated $50 \%$ effective dose $\left(E^{2} D_{50}\right)$ of $0.07 \mathrm{nM}$ (Fig. 3). At the maximal stimulatory dose, $79 \%$ of intracellular GH content was released during the 4-h incubation period. In cells from $T x$ rats the $\mathrm{ED}_{50}$ for hGRH was increased threefold to $0.20 \mathrm{nM}(P<0.05$ vs. control) and only $44 \%$ of the $\mathrm{GH}$ content was released at maximal stimulation $(P<0.005$ vs. control). Cells from $\mathrm{T}_{4} \mathrm{Rx}$ rats exhibited a partial recovery of $\mathrm{GRH}$ responsiveness with an $\mathrm{ED}_{50}$ of $0.11 \mathrm{nM}(P=\mathrm{NS}$ vs. control and $\mathrm{Tx})$ and a maximal response of $72 \%$ of cell content $(P$ $=$ NS vs. control; $<0.005$ vs. Tx). The slopes of the dose-response curves in the three groups were statistically indistinguishable.

Effect of thyroidectomy on pituitary cAMP responses to $G R H$. cAMP generation in response to GRH was compared at a dose
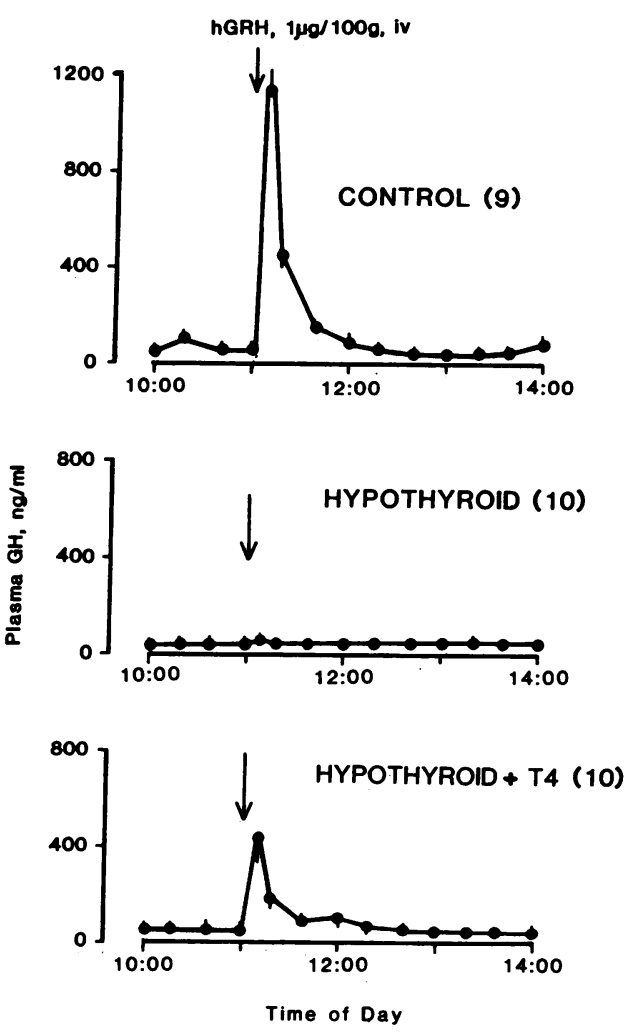

Figure 2. Effect of intravenous injection of hGRH $(1 \mu \mathrm{g} / 100 \mathrm{~g})$ on plasma GH levels in control, thyroidectomized, and thyroidectomized-thyroxine-treated animals. GRH was injected at $1100 \mathrm{~h}$. Shown are the mean \pm SE. The number of animals studied is indicated in parentheses.

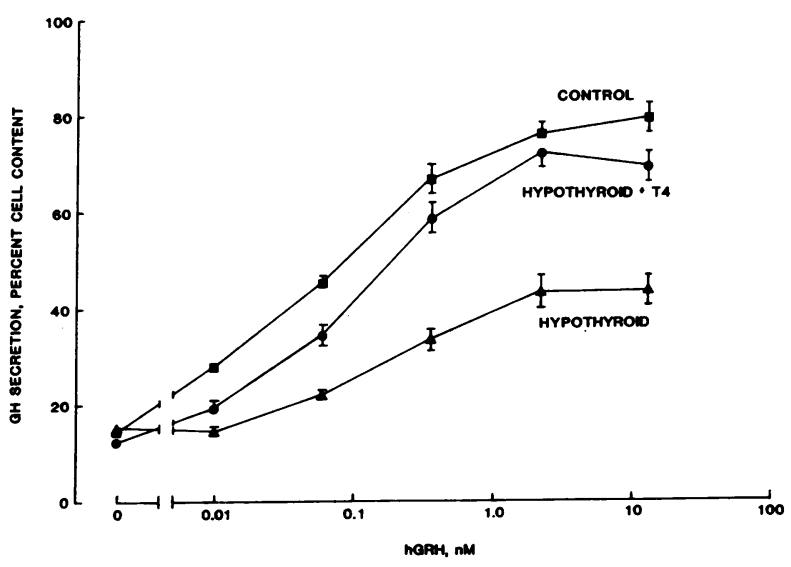

Figure 3. Dose-related stimulation of GH release by GRH in pituitary cell cultures obtained from control, thyroidectomized, and thyroidectomized-thyroxine-treated animals. GH secretion is expressed as the percentage of intracellular GH content released during the 4-h incubation. Shown are the mean \pm SE of three separate experiments, each performed with quadruplicate incubations of $2.5 \times 10^{5}$ cells/well. Basal GH release in control, thyroidectomized, and thyroidectomized-thyroxine-treated groups was $3,204 \pm 132,218 \pm 18$, and $2,030 \pm 192 \mathrm{ng} /$ well per $4 \mathrm{~h}$, respectively. The calculated $\mathrm{ED}_{50}$ for the control, thyroidectomized, and thyroidectomized-thyroxine-treated groups were 0.07 , 0.20 , and $0.11 \mathrm{nM}$, respectively. 
Table II. Effect of Thyroidectomy on Intracellular cAMP Responses to hGRH

\begin{tabular}{llll}
\hline & \multicolumn{3}{l}{ Intracellular cAMP (pmol/2.5 $\times 10^{5}$ cells) } \\
\cline { 2 - 4 } & Basal & $\begin{array}{l}\text { hGRH }(0.1 \\
\text { nM) }\end{array}$ & hGRH $(13 \mathrm{nM})$ \\
\hline Control & $1.27 \pm 0.06^{*}$ & $2.27 \pm 0.19 \ddagger$ & $25.54 \pm 2.27 \ddagger$ \\
Hypothyroid & $1.24 \pm 0.10$ & $1.47 \pm 0.15$ & $2.20 \pm 0.26 \ddagger$ \\
$P$ vs. control & $\mathrm{NS}$ & $<0.01$ & $<0.01$ \\
Hypothyroid $+\mathrm{T}_{4}$ & $1.61 \pm 0.07$ & $2.05 \pm 0.11 \S$ & $4.87 \pm 0.39 \ddagger$ \\
$P$ vs. control & $<0.05$ & $\mathrm{NS}$ & $<0.01$ \\
$P$ vs. Tx & $<0.05$ & $<0.05$ & $<0.01$ \\
& & & \\
\hline
\end{tabular}

* Mean $\pm \operatorname{SE}(n=12$, three separate experiments).

$\ddagger P<0.01$ vs. basal.

$\S P<0.05$ vs. basal.

near the $\mathrm{ED}_{50}$ for $\mathrm{GH}$ release $(0.1 \mathrm{nM})$ and at a dose evoking a maximal $\mathrm{GH}$ response (13 $\mathrm{nM}$ ). In the absence of $\mathrm{GRH}$, intracellular cAMP levels were comparable in control and Tx cells while being slightly increased in $\mathrm{T}_{4} \mathrm{Rx}$ cells (Table II). Pituitary cAMP levels in control cells increased by $1.8 \times$ in response to the lower dose of hGRH and $20.1 \times$ in response to the higher dose. In contrast, there was a minimal $(1.2 \times)$ increase in cAMP levels in pituitaries from $T x$ rats with $0.1 \mathrm{nM}$ GRH and only a $1.6 \times$ increase with the higher dose. In pituitaries of $T_{4} R x$ animals, partial recovery of the cAMP response was observed, but the increases (1.3X and 3.0 $\times$ at low and high concentrations) were considerably less than in controls.

Effect of thyroidectomy on the inhibition of $G H$ release by somatostatin. Sensitivity to SRIF was evaluated by determining its inhibitory effects in cells stimulated by hGRH at a concentration of $0.1 \mathrm{nM}$. SRIF caused a progressive inhibition of $\mathrm{GH}$ secretion beginning at a concentration of $0.03 \mathrm{nM}$ and exhibited a $50 \%$ inhibitory concentration $\left(\mathrm{IC}_{50}\right)$ of $0.43 \mathrm{nM}$ in control cells (Fig. 4). Greater sensitivity to the suppressive effects of SRIF were observed in cells from $\mathrm{Tx}$ rats with an $\mathrm{IC}_{50}$ of $0.10 \mathrm{nM}(P$ $<0.01$ vs. controls). Cells from $\mathrm{T}_{\mathbf{4}} \mathrm{Rx}$ animals were less sensitive to SRIF ( IC $\left._{50}: 0.20 \mathrm{nM}\right)$ than were cells from Tx animals $(P$ $<0.01$ ), though they continued to exhibit greater sensitivity than did controls.

Effect of thyroidectomy on hypothalamic GRH content. Immunoreactive GRH levels in the three groups are shown in Table III. In Tx animals, hypothalamic GRH content was decreased by $50 \%$ while $\mathrm{T}_{4}$ treatment restored GRH content to levels indistinguishable from those of controls.

\section{Discussion}

The present results indicate that the effects of thyroid hormone deficiency are complex and include actions at multiple sites involved in the regulation of GH secretion. The use of a combined in vivo/in vitro experimental design permitted the examination of individual components of this regulatory system in the same animals and also allowed an assessment of the relative importance of each in the overall impairment of $\mathrm{GH}$ secretion.

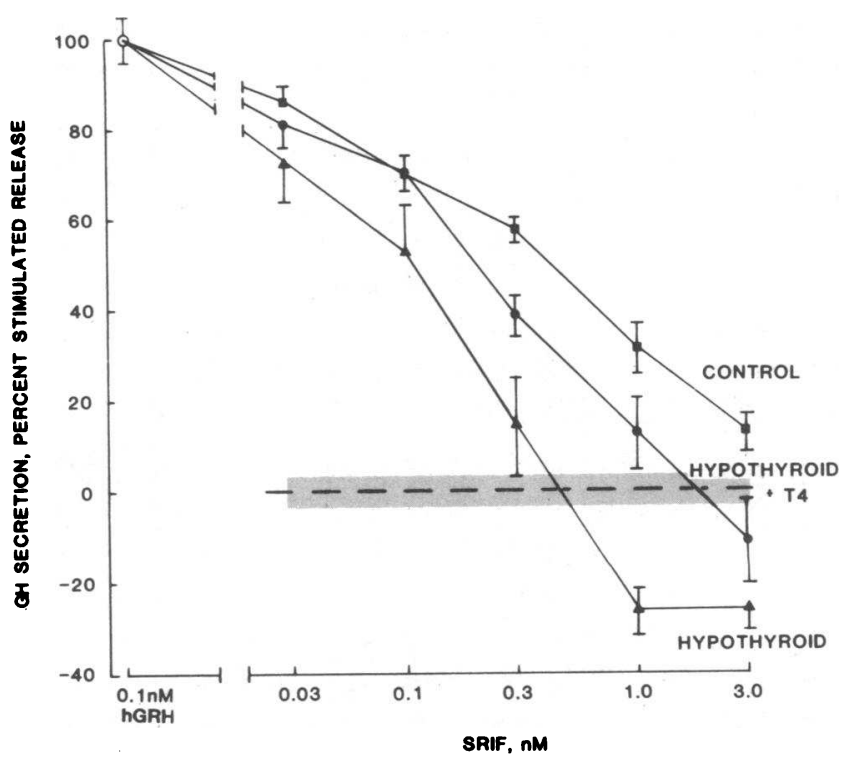

Figure 4. Dose-related inhibition by SRIF of GRH-stimulated ( 0.1 nM) GH release in cultured pituitary cells obtained from control, thyroidectomized, and thyroidectomized-thyroxine-treated animals. Shown are the mean \pm SE of three separate experiments, each performed with quadruplicate incubations of $2.5 \times 10^{5}$ cells/well. The shaded area represents the mean $\pm \mathrm{SE}$ of basal $\mathrm{GH}$ release. The calculated $\mathrm{IC}_{50}$ for control, thyroidectomized, and thyroidectomized-thyroxine-treated groups were $0.43,0.10$, and $0.20 \mathrm{nM}$, respectively.

GH secretion in the conscious rat is pulsatile with secretory bursts occurring regularly at $3-4$-h intervals $(17,27)$. The effect of thyroidectomy on spontaneous $\mathrm{GH}$ secretion was profound in that virtually no ultradian secretory episodes were detectable and most plasma GH levels were at or beneath the limit of detection of the assay. The $\mathrm{GH}$ response to an intravenous injection of GRH was similarly affected by thyroidectomy with the reduction in the peak secretory response being virtually complete. Short-term thyroxine treatment resulted in a dissociation in the recovery of spontaneous as compared to exogenously stimulated $\mathrm{GH}$ secretion. After $4 \mathrm{~d}$ of thyroxine administration and, at a time when TSH levels and pituitary GH content had not yet returned to control values, spontaneous GH secretion was fully restored to normal. Recovery of GRH-stimulated GH release, however, was considerably slower with considerable impairment

Table III. Effect of Thyroidectomy on Hypothalamic GRH Content

\begin{tabular}{lrl}
\hline & & Rat GRH \\
\hline & $n$ & $n g /$ hypothalamus \\
Control & 10 & $0.90 \pm 0.06$ \\
Hypothyroid & 10 & $0.45 \pm 0.04^{*}$ \\
Hypothyroid $+\mathrm{T}_{4}$ & 9 & $0.96 \pm 0.05 \ddagger$
\end{tabular}

$* P<0.01$ vs. control.

$\ddagger P<0.01$ vs. hypothyroid. 
noted even after $6 \mathrm{~d}$ of treatment. Spontaneous GH secretion thus was restored to normal well before full replenishment of the GH secretory reserve.

These impairments in $\mathrm{GH}$ secretion in vivo were reflected by corresponding changes in pituitary $\mathrm{GH}$ content and release in vitro. Although the experimental design did not permit measurement of total GH content of intact pituitaries, the level of GH in dispersed pituitary cells of thyroidectomized animals was markedly reduced and the use of autologous serum during the $3 \mathrm{~d}$ of primary culture maintained the hypothyroid environment until the time of testing with GRH and SRIF. Thyroxine treatment restored intracellular GH content to a level that closely reflected the recovery of the GH secretory response to GRH in vivo. The latter thus appears to be a reliable indicator of the total GH content of the somatotrophs. The results also indicate that normal spontaneous GH secretion can occur with a substantial reduction in total $\mathrm{GH}$ content.

Despite the marked reduction of pituitary GH content in hypothyroid animals, the percentage of stored $\mathrm{GH}$ that was released in vitro under basal conditions was comparable to controls. These results provided the rationale for analyzing the GH secretory response to GRH as a function of the total cell content and allowed for a meaningful comparison of the three experimental groups despite large differences in somatotroph $\mathrm{GH}$ stores.

The effects of GRH on somatotrophs from hypothyroid rats were quantitatively and qualitatively different from those on controls. Maximal GH release from hypothyroid somatotrophs was reduced by nearly $50 \%$ and the $\mathrm{ED}_{50}$ was increased threefold. These alterations imply at least two different effects of thyroid hormone deficiency. The increased $\mathrm{ED}_{\mathbf{s 0}}$ could be explained by a decrease in the number of somatotroph GRH receptors. Thyroid hormone has been shown to decrease pituitary TRH receptors $(28,29)$ and reciprocal effects on GRH receptors could explain the changes. These findings are in agreement with the report by Vale et al. (30) that the addition of $T_{3}$ in vitro decreases the $\mathrm{ED}_{50}$ of $\mathrm{GRH}$ for $\mathrm{GH}$ release in normal pituitary cells. They are at variance, however, with the results of Dieguez et al. (14) that suggested an absence of an alteration in the $\mathrm{ED}_{50}$ for $\mathrm{GRH}$ in hypothyroid rats. Less severe hypothyroidism and variations in culture conditions would appear to explain the differences between that study and the present results. The decrease in hypothalamic GRH content observed in the present study could also result in reduced GRH delivery to the pituitary, which may contribute to changes in the somatotroph GRH receptor. The lack of deviation from parallelism of the GRH dose-response curves argues against a change in the $\mathrm{ED}_{50}$ due to an effect of thyroid hormone deficiency on the binding affinity of the GRH receptor.

The decrease in maximal GH response, however, requires a different explanation since it has been reported that only 10$20 \%$ occupancy of GRH receptors is required for a maximal biologic response (31). This suggests that thyroid hormone deficiency modifies the GRH-releaseable pool of somatotroph GH or leads to an impairment of a postreceptor process. Evidence for such a defect was uncovered by measurement of intracellular cAMP levels. No differences were observed in basal cAMP levels in pituitaries from hypothyroid and control rats, though the contribution of somatotrophs, which constitutes only $30 \%$ of total pituitary cells in male rats (32) to this measurement cannot be determined from the present study. However, in response to
GRH, a marked impairment of cAMP accumulation was noted in hypothyroid rats. Since cAMP is believed to mediate, at least in part, the GH-releasing effect of GRH $(21,33-36)$ as well as its effects on GH synthesis (37-39), our results suggest that hypothyroidism leads to a defect in adenylate cyclase function or in its linkage to the GRH receptor.

Somatotrophs from thyroxine-treated rats exhibited a reduction in the $\mathrm{ED}_{50}$ for $\mathrm{GRH}$, an increase in the maximal $\mathrm{GH}$ response, and an increase in cAMP generation as compared to hypothyroid rats. The effects of thyroxine on the $\mathrm{ED}_{50}$ and on cAMP were only partial, which is most likely explained by the limited duration of treatment. It emphasizes, however, that complete recovery of these parameters of GRH action need not occur in order to have full restoration of spontaneous $\mathrm{GH}$ secretion in vivo. The relatively minimal recovery of cAMP generation, in particular, is noteworthy since it implies that only a small increase in this intracellular messenger may be required for normal spontaneous GH secretion. This observation of a smaller fractional increase in cAMP generation than in GH secretion is consistent with the reported differences in the $\mathrm{ED}_{50}$ of GRH for these two parameters (21).

Another intrapituitary effect contributing to the impaired GH secretion in thyroid hormone deficiency is the enhancement of sensitivity to SRIF. Hypothyroidism is associated with decreased SRIF secretion (10) and it is tempting to speculate that this, in turn, could result in an increase in SRIF receptor density on the somatotroph $(40,41)$. Although Hinkle et al. (42) failed to uncover any consistent changes in SRIF receptors by in vitro addition and/or deletion of thyroid hormone to pituitary tumor cell cultures, changes occurring in response to hypothyroidism in vivo may still occur. As with GRH, thyroxine treatment only partially restored SRIF sensitivity to normal at the time of study.

The other major locus at which thyroid hormone deficiency could influence GH secretion is the hypothalamus and the present study has demonstrated a highly significant reduction in hypothalamic GRH levels in hypothyroid animals. Although the sensitivity of our assay was insufficient to quantitate release of GRH from the hypothalamus, such an effect would be expected if content and release of GRH are related as are those of SRIF (10). In contrast to the effects of thyroxine replacement on the pituitary, which were only partial, hypothalamic GRH levels were restored completely to control levels.

This study thus has demonstrated four effects of thyroid hormone deficiency, in addition to the previously recognized decrease in $\mathrm{GH}$ synthesis, that contribute to the impaired secretion of $\mathrm{GH}$ in vivo: $(a)$ decreased $\mathrm{ED}_{50}$ and maximal response to GRH in vitro, $(b)$ impaired cAMP accumulation in response to GRH, $(c)$ increased sensitivity $\left(\mathrm{IC}_{50}\right)$ to SRIF, and $(d)$ decreased hypothalamic GRH content. While the present data cannot quantitatively differentiate the relative contributions of each of these actions on the impairment of GH secretion seen in vivo, two conclusions seem warranted. First, the marked reduction of pituitary GH content observed in severe hypothyroidism overshadows the other effects and is, without question, the quantitatively most significant factor in the nearly complete absence of GH secretion. Second, complete recovery of spontaneous GH secretion occurs at a time when GH content and both the $\mathrm{GH}$ secretory response and the cAMP stimulatory response to GRH are still impaired, but when hypothalamic GRH content is restored to normal. This suggests that the most critical effect of thyroid hormone in maintaining normal GH secretion occurs 
in the hypothalamus and is related to preservation of the normal secretion of GRH.

\section{Acknowledgments}

Materials for the rat GH and TSH RIA were provided by the National Hormone and Pituitary Program. We thank Jeanne Hirth for technical assistance and Dr. I-Wen Chen for the $T_{4}$ measurements.

This work was supported by U. S. Public Health Service grants AM 30667 and RR 0068-23.

\section{References}

1. Eberhardt, N. W., J. W. Apriletti, and J. B. Baxter. 1980. The molecular biology of thyroid hormone action. In Biochemical Actions of Hormones. Vol. 7. G. Litwak, editor. Academic Press, New York. 311-394.

2. Iwatsubo, H., K. Omori, Y. Okada, M. Fukuchi, K. Miyai, H. Abe, and Y. Kumahara. 1967. Human growth hormone secretion in primary hypothyroidism before and after treatment. J. Clin. Endocrinol. Metab. 27:1751-1754.

3. MacGillivray, M. H., T. Aceto, and L. A. Frohman. 1968. Plasma growth hormone response and growth retardation of hypothyroidism. Am. J. Dis. Child. 115:273-276.

4. Chernausek, S. D., L. E. Underwood, R. D. Utiger, and J. J. Van Wyk. 1983. Growth hormone secretion and plasma somatomedin-C in primary hypothyroidism. Clin. Endocrinol. 19:337-344.

5. Solomon, J., and R. O. Greep. 1959. The effect of alteration in thyroid function on the pituitary growth hormone content and acidophil cytology. Endocrinology. 65:158-164.

6. Peake, G. T., C. A. Birge, and W. H. Daughaday. 1973. Alterations of radioimmunoassayable growth hormone and prolactin during hypothyroidism. Endocrinology. 92:487-493.

7. Takeuchi, A., M. Suzuki, and S. Tsuchiya. 1978. Effect of thyroidectomy on the secretory profiles of growth hormone, thyrotropin and corticosterone in the rat. Endocrinol. Jpn. 25:381-390.

8. Hervas, F., G. M. Morreale de Escobar, and F. E. Escobar del Rey. 1975. Rapid effect of single small doses of 1-thyroxine and triiodo1-thyronine on growth hormone, as studied in the rat by radioimmunoassay. Endocrinology. 97:91-101.

9. Coiro, V., L. E. Braverman, D. Christianson, S. T. Fang, and H. M. Goodman. 1979. Effect of hypothyroidism and thyroxine replacement on growth hormone in the rat. Endocrinology. 105:641-646.

10. Berelowitz, M., K. Maeda, S. Harris, and L. A. Frohman. 1980. The effect of alterations in the pituitary-thyroid axis on hypothalamic content and in vitro release of somatostatin-like immunoreactivity. $E \boldsymbol{n}$ docrinology. 107:24-29.

11. Berelowitz, M., S. L. Firestone, and L. A. Frohman. 1981. Effects of growth hormone excess and deficiency on hypothalamic somatostatin content and release and on tissue somatostatin distribution. Endocrinology. 109:714-719.

12. Guillemin, R., P. Brazeau, P. Bohlen, F. Esch, N. Ling, and W. B. Wehrenberg. 1982. Growth hormone-releasing factor from a human pancreatic tumor that caused acromegaly. Science (Wash. DC). 21: 585-587.

13. Rivier, J., J. Spiess, M. Thorner, and W. Vale. 1982. Characterization of a growth hormone releasing factor from a pancreatic islet tumor. Nature (Lond.). 300:276-278.

14. Dieguez, C., S. M. Foord, J. R. Peters, R. Hall, and M. F. Scanlon. 1985. The effects of thyroid hormone deprivation in vivo and in vitro on growth hormone (GH) responses to human pancreatic (tumor) $\mathrm{GH}$ releasing factor (1-40) by dispersed rat anterior pituitary cells. Endocrinology. 116:1066-1070.

15. Root, J. L., G. E. Duckett, M. Sweetland, J. A. Strzelecki, and A. W. Root. 1985. Hypothyroidism blunts the growth hormone (GH) releasing effect of human pancreatic $\mathrm{GH}$ releasing factor in the adult male rat in vivo and in vitro. Endocrinology. 116:1703-1706.

16. Williams, T., H. Maxon, M. O. Thorner, and L. A. Frohman. 1985. Blunted growth hormone response to growth hormone-releasing hormone in hypothyroidism resolves in the euthyroid state. J. Clin. Endocrinol. Metab. 61:454-456.

17. Katakami, H., Y. Kato, N. Matsushita, S. Hiroto, A. Shimatsu, and $\mathrm{H}$. Imura. 1981. Involvement of alpha-adrenergic mechanisms in growth hormone release induced by opioid peptides in conscious rats. Neuroendocrinology. 33:129-135.

18. Katakami, H., Y. Kato, N. Matsushita, A. Shimatsu, and H. Imura. 1981. Possible involvement of $\gamma$-aminobutyric acid in growth hormone release induced by a met ${ }^{5}$-enkephalin analog in conscious rats. Endocrinology. 109:1033-1036.

19. Katakami, H., A. Arimura, and L. A. Frohman. 1985. Hypothalamic somatostatin mediates the suppression of growth hormone secretion by centrally administered thyrotropin-releasing hormone in conscious rats. Endocrinology. 117:1139-1144.

20. Wilfinger, W. W., W. J. Larsen, T. R. Downs, and D. L. Wilbur. 1984. An in vitro model for studies of intercellular communication in cultured rat anterior pituitary cells. Tiss. Cell. 16:483-497.

21. Bilezikjian, L. M., and W. W. Vale. 1983. Stimulation of adenosine $3^{\prime}, 5^{\prime}$-monophosphate production by growth hormone-releasing factor and its inhibition by somatostatin in anterior pituitary cells in vitro. Endocrinology. 113:1726-1731.

22. Frohman, L. A., and L. L. Bernardis. 1968. Growth hormone and insulin levels in weanling rats with ventromedial hypothalamic lesions. Endocrinology. 82:1125-1132.

23. Szabo, M., and L. A. Frohman. 1976. Dissociation of prolactinreleasing activity from thyrotropin-releasing hormone in porcine stalk median eminence. Endocrinology. 98:1451-1459.

24. Livesey, J. H., and R. A. Donald. 1982. Prevention of adsorption losses during radioimmunoassay of polypeptide hormones: effectiveness of albumins, gelatin, caseins, Tween 20, and plasma. Clin. Chim. Acta. 123:193-198.

25. DeLean, A., P. J. Munson, and D. Rodbard. 1978. Simultaneous analysis of families of sigmoidal curves: application to bioassay, radioligand, and physiological dose-related response curves. Am. J. Physiol. 235:E97-E102.

26. Snedecor, G. W. 1956. Statistical Methods. Covariance. Fifth ed. Iowa University Press, Ames. 394-412.

27. Tannenbaum, G. S., and J. B. Martin. 1976. Evidence for an endogenous ultradian rhythm governing growth hormone secretion in the rat. Endocrinology. 98:562-570.

28. de Lean, A., L. Ferland, J. Drouin, P. A. Kelly, and F. Labrie. 1977. Modulation of pituitary thyrotropin releasing hormone receptor levels by estrogens and thyroid hormones. Endocrinology. 100:14961504.

29. Hinkle, P. M., and K. B. C. Goh. 1982. Regulation of thyrotropinreleasing hormone receptors and responses by 1-triiodothyronine in dispersed rat pituitary cell cultures. Endocrinology. 110:1725-1731.

30. Vale, W., J. Vaughan, G. Yamamoto, J. Spiess, and J. Rivier. 1983. Effects of synthetic human pancreatic (tumor) GH releasing factor and somatostatin, triiodothyronine and dexamethasone on GH secretion in vitro. Endocrinology. 112:1553-1555.

31. Velicelebi, G., T. M. Santacroce, and M. M. Harpold. 1985. Specific binding of synthetic human pancreatic growth hormone releasing factor (1-40-OH) to bovine anterior pituitaries. Biochem. Biophys. Res. Commun. 126:33-39.

32. Hymer, W. C., W. H. Evans, J. Kraicer, A. Mastro, J. Davis, and E. Griswold. 1973. Enrichment of cell types from the rat adenohypophysis by sedimentation at unit gravity. Endocrinology. 92:275-287.

33. Cronin, M. J., E. L. Hewlett, W. S. Evans, M. O. Thorner, and A. D. Rogol. 1984. Human pancreatic tumor growth hormone (GH)releasing factor and cyclic adenosine 3',5'-mono-phosphate evoke GH release from anterior pituitary cells: the effects of pertussis toxin, cholera toxin, forskolin, and cycloheximide. Endocrinology. 114:904-915. 
34. Schettini, G., M. J. Cronin, E. L. Hewlett, M. O. Thorner, and R. M. MacLeod. 1984. Human pancreatic tumor growth hormone-releasing factor stimulates anterior pituitary adenylate cyclase activity, adenosine 3 ',5'-monophosphate accumulation, and growth hormone release in a calmodulin-dependent manner. Endocrinology. 115:1308-1314.

35. Harwood, J. P., C. Grewe, and G. Aguilera. 1984. Actions of growth hormone-releasing factor and somatostatin on adenylate cyclase and growth hormone release in rat anterior pituitary. Mol. Cell. Endocrinol. 37:277-284.

36. Culler, M. D., T. Kenjo, N. Obara, and A. Arimura. 1984. Stimulation of pituitary cAMP accumulation by human pancreatic GH-releasing factor-(1-44). Am. J. Physiol. 247:E609-615.

37. Szabo, M., L. Chu, and L. A. Frohman. 1982. Biological effects of an ectopic growth hormone-releasing peptide in cultured adenohypophyseal cells: Comparison with growth hormone-releasing activity of porcine hypothalamus. Endocrinology. 111:1235-1240.

38. Gick, G. G., F. N. Zeytin, P. Brazeau, N. C. Ling, F. S. Esch, and C. Bancroft. 1984. Growth hormone-releasing factor regulates growth hormone mRNA in primary cultures of rat pituitary cells. Proc. Natl. Acad. Sci. USA. 81:1553-1555.

39. Barinaga, M., L. M. Bilezikjian, W. W. Vale, M. G. Rosenfeld, and R. M. Evans. 1985. Independent effects of growth hormone releasing factor on growth hormone release and gene transcription. Nature (Lond.). 314:279-281.

40. Srikant, C. B., and Y. C. Patel. 1984. Cysteamine-induced depletion of brain somatostatin is associated with up-regulation of cerebrocortical somatostatin receptors. Endocrinology. 115:990-995.

41. Katakami, H., M. Berelowitz, M. Marbach, and L. A. Frohman. 1985. Modulation of somatostatin binding to rat pituitary membranes by exogenously administered growth hormone. Endocrinology. 117:557560 .

42. Hinkle, P. M., M. H. Perrone, and A. Schonbrunn. 1981. Mechanism of thyroid hormone inhibition of thyrotropin-releasing hormone action. Endocrinology. 108:199-205. 